\title{
Isotope hydrological studies of the perennial ice deposit of Saarhalle, Mammuthöhle, Dachstein Mts, Austria
}

\author{
Z. Kern ${ }^{1, *}$, I. Fórizs ${ }^{1}$, R. Pavuza ${ }^{2}$, M. Molnár ${ }^{3}$, and B. Nagy ${ }^{4}$ \\ ${ }^{1}$ Institute for Geochemical Research, Hungarian Academy of Sciences, Budapest, Hungary \\ ${ }^{2}$ Department of Karst and Cave Science at the Museum of Natural History, Vienna, Austria \\ ${ }^{3}$ Institute of Nuclear Research of the Hungarian Academy of Sciences, Hungary \\ ${ }^{4}$ Department of Physical Geography, Eötvös Loránd University, Budapest, Hungary \\ *now at: Department of Palaeontology, Eötvös Loránd University, Budapest, Pázmány Péter str. 1/c, H-1117, Hungary
}

Received: 13 August 2010 - Published in The Cryosphere Discuss.: 26 August 2010

Revised: 21 March 2011 - Accepted: 22 March 2011 - Published: 29 March 2011

\begin{abstract}
A $5.28 \mathrm{~m}$-long ice core was extracted from a major cave ice body in the Mammuthöhle cave system. The upper $\sim 1.2 \mathrm{~m}$ of ice most likely originate from precipitation fallen before the 1960s (based on $<8.5 \mathrm{TU}$ ). Characteristic fluctuations in electrical conductivity were observed in the cave ice profile, which seem to mirror the fluctuation of karst and surface water in the water supply of the ice accumulation. The stable isotope composition does not support the hypothesis that ice layers with low conductivity are formed by freezing out of water vapour. Isotope fractionation effects during the freezing process are indicated by the enrichment of heavy stable isotopes $\left({ }^{2} \mathrm{H},{ }^{18} \mathrm{O}\right)$ in the ice compared to the potential sources (local precipitation, karst water) and by the characteristically low $d$-excess values. In addition, the cave ice water line shows a slope coefficient of 8.13. A two-component open-system model (i.e. a depleted component mixed with the freezing water) can adequately explain the measured isotopic compositions of the Saarhalle cave ice.
\end{abstract}

\section{Introduction}

Mid-latitude glaciers are well-known archives of past environmental conditions (e.g. Wagenbach, 1989; Schwikowski, 2004). Traditional methodological protocols favour glaciated terrains located in the dry firn or cold percolation zones with relatively high accumulation rates. Due to basic glaciological constraints, however, the available time span of these records

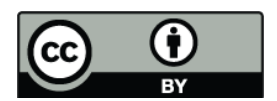

Correspondence to: Z. Kern

(kern@geochem.hu) is limited. Recently, researchers have started to explore previously neglected low-accumulation environments (Wagenbach and Spötl, 2010) such as miniature ice caps (Haeberli et al., 2004) and perennial cave ice accumulations (Claussen et al., 2007; Holmlund et al., 2005; Turri et al., 2009; May et al., 2011). The latter, however, can have a complex origin as their water can be derived from snow, freezing karst water, or freezing out (re-sublimation) of water vapour. The relative importance of these sources can vary from cave to cave and it is unrealistic to expect that a single model can be used to interpret environmental proxies (e.g. accumulation rate, isotope fluctuations) from cave ice deposits. For instance, cave ice was found to be significantly isotopically enriched compared to local mean annual precipitation (e.g. Lauriol and Clark, 1993; Fórizs et al., 2004; Claussen et al., 2007; Perşoiu et al., 2007; May et al., 2011). This is not a general rule, however, because cave ice locally is comparable or even more depleted than the local precipitation (e.g. Yonge and MacDonald, 2006; Luetscher et al., 2007; Kern et al., 2009a). Detailed studies are therefore required for each individual ice cave to understand these systems (Yonge and MacDonald, 2006; Turri et al., 2009).

Mammuthöhle is one of a series of alpine caves where stratified perennial ice exists.

The main purposes of this paper are:

- to explore the origin of the water forming the Saarhalle perennial cave ice accumulation, and

- to evaluate the potential of this ice deposit for further palaeoclimatological and palaeoenvironmental studies.

Published by Copernicus Publications on behalf of the European Geosciences Union. 

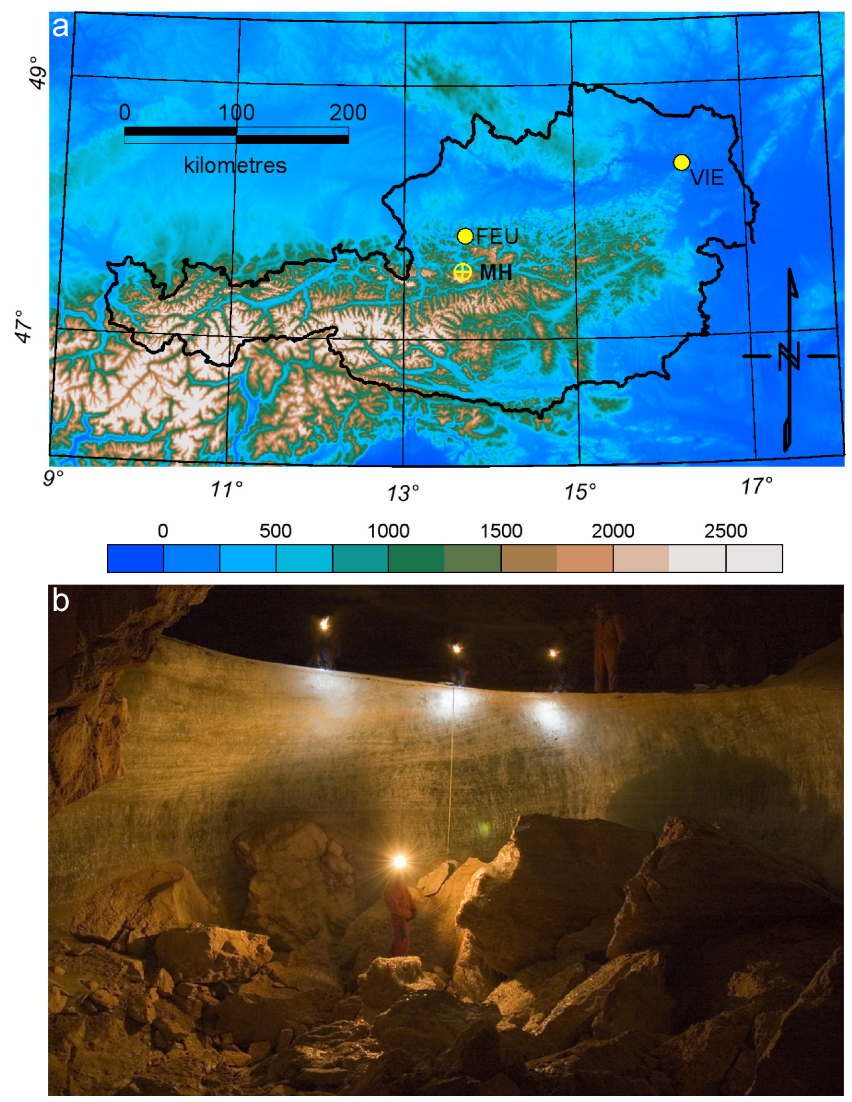

Fig. 1. (a) Relief map of Austria (elevation in ma.s.1.) showing the location of Mammuthöhle (MH) and the reference stations (Feuerkogel: FEU and Vienna: VIE), (b) cliff of the Saarhalle ice body.

\section{Site description}

Mammuthöhle system is located in the Dachstein Mts of the Northern Calcareous Alps (Fig. 1a). The total length of all passages in Mammuthöhle amounts to $65 \mathrm{~km}$, and the vertical extension is $1207 \mathrm{~m}$ which makes it the third longest and fifth deepest cave in Austria. The host rock is Upper Triassic Dachstein Limestone. Mammuthöhle has a long and complex history (Plan and Xaver, 2010) and its large phreatic parts (halls and galleries) are believed to have formed $\sim 10$ Ma ago (Frisch et al., 2002).

Twenty-one entrances are currently known and the highest one is located at $1828 \mathrm{~m}$ a.s.l. while the deepest entrance opens at $1259 \mathrm{~m}$ a.s.l. Due to these multiple entrances situated at different elevations a complex ventilation regime characterizes this cave system. One of the ventilation subsystems includes the western part of the cave where Saarhalle is located. The characteristic seasonal air flow within the system is directed inward during winter and outward during summer. The Saarhalle, however, shows a particularly unique sub-regime within the main classical dynamic system, inasmuch as no air movement could be detected in this large chamber after the system's switch to the summer ventilation mode. Consequently, Saarhalle is regarded as a chamber with rather sluggish ("static") ventilation.

The effect of winter cooling in some parts of the western subsystem is sufficient to maintain permanent cave glaciation. Two chambers host major ice deposits, i.e. Feenpalast and Saarhalle. The Saarhalle ice body (Fig. 1b) is the larger one. Its extension is 40 by $15 \mathrm{~m}$ and the estimated maximum ice thickness is $\sim 6 \mathrm{~m}$ (Behm and Hausmann, 2008). The sediment substrate is dominated by large boulders and the ice body rests in a bowl-like depression (Behm and Hausmann, 2007; Hausmann and Behm, 2010) so lateral ice flow or sliding is regarded unlikely.

The western entrance (1392 ma.s.l.) opens close to Saarhalle whose exact location within the large cave system is shown in the cave map (see Supplement).

A temperature monitoring network was installed in Mammuthöhle between 1999 and 2000. The monitoring data revealed that the air temperature in the Saarhalle follows the temperature fluctuations of the Feenpalast with a reduced amplitude during the winter ventilation regime $(\sim$ from November to early May, Mais and Pavuza, 2000). This suggests that the cold outside air enters the Saarhalle chamber via the Feenpalast. On the other hand, air temperature rises slightly above the freezing point $\left(0.1-0.2^{\circ} \mathrm{C}\right)$ during the rest of the year. Ice accumulation is thus unlikely during summer. In addition, no ice forms during the maximum winter cooling when cold surface air invades the system, dries up upon warming inside the cave and causes sublimation of the ice surface. This process has been described from the Eisriesenwelt system (Obleitner and Spötl, 2011) which shows a similar bidirectional dynamic ventilation pattern, and has been studied in details in other (e.g. cold trap-like) ice caves during the winter mode (e.g. Rajman et al., 1987; Perşoiu 2004). The only period when ice accumulates is the spring season when very cold snow melt enters those passages of the cave that have been chilled by the winter ventillation.

The mean annual air temperature in the Saarhalle ranged from $-0.10^{\circ} \mathrm{C}$ to $-0.46^{\circ} \mathrm{C}$ in the $1996-2000$ period, and the long-term average was $-0.30^{\circ} \mathrm{C}$. The ice level shows a steady decrease since 1996 at a nearly constant rate of $7 \mathrm{~cm} \mathrm{yr}^{-1}$ (Mais and Pavuza, 2000; unpubl. data). Rock overburden above Saarhalle is estimated to $60 \mathrm{~m}$.

Following the process-based classification of alpine ice caves (Luetscher and Jeannin, 2004) the Mammuthöhle system can be classified as a dynamic cave with congelation ice, but within this large dynamic system Saarhalle can be regarded as a static chamber.

Radiocarbon dating of a wood remnant found at the base of Feenpalast's ice body ten years ago yielded an age of $695 \pm 35 \mathrm{yr}$ (sample GrA-14417; Mais and Pavuza, 2000). The calibration provides two separate intervals for the two-sigma range (1259-1352 cal AD 68.3\%, and 1318$1390 \mathrm{cal}$ AD $27.1 \%$ ) using the current calibration dataset (Reimer et al., 2009). This suggests at least $600 \mathrm{yr}$-old ice 
at the base of the Feenpalast ice body. This date, however, might have little relevance for the age of the Saarhalle ice body as this chamber is situated in a more remote sector of the system. So far, no macroscopic organic material was found in the ice of Saarhalle.

\section{Materials and methods}

\subsection{Ice drilling}

We extracted an ice core from the ice body of Saarhalle in September 2009 with a manual drilling equipment. The location of the drill site was selected using Ground Penetrating Radar (GPR). The drilling was made on the flat surface of the ice where GPR sounding suggested a maximum ice thickness of $6 \mathrm{~m}$ and pronounced layered internal structure (Hausmann and Behm, 2010). The $5.28 \mathrm{~m}$-long core (diameter $3 \mathrm{~cm}$ ) was split into 105 subsamples labelled MH1 to MH105, starting from the surface of the ice body downwards, each $\sim 5 \mathrm{~cm}$ long. One sample (MH7) was lost during sampling. Each subsample was put into a dry, clean and sterile $120 \mathrm{ml}$ plastic bag. In the laboratory the samples were allowed to melt completely, $12 \mathrm{ml}$ of water were pipetted into glass vials and stored in a refrigerator for stable isotope analysis. The rest of the samples was used for tritium concentration and electrolytic conductivity measurements. The level of the ice was anchored before the coring and all depth data is referred to as "depth below the September 2009 ice surface".

\subsection{Tritium measurements}

Tritium activities were determined using a liquid scintillation counting (LSC) technique on eight non-neighbouring samples (MH1, MH4, MH8, MH10, MH13, MH16, MH19, MH22) spread over the upper $1.2 \mathrm{~m}$-long part of the core. Water samples were distilled before LSC measurements to minimize quenching (Svetlik and Budska, 2001). $10 \mathrm{~mL}$ of distilled water was mixed with $10 \mathrm{~mL}$ of Ultima Gold LLT cocktail in a low-diffusion PE-vial and measured using a Wallac 1220 Quantulus (Perkin Elmer) ultra-low level liquid scintillation spectrometer at the Institute of Nuclear Research Hungarian Academy of Sciences. Measuring time was $750 \mathrm{~min}$ per sample, resulting in a critical level $\left(\mathrm{L}_{\mathrm{C}}\right)$ of 8.5 TU (tritium units, $1 \mathrm{TU}=0.1183 \mathrm{BqL}^{-1}$; Curie, 1995). The $\mathrm{L}_{\mathrm{C}}$ was fairly high as it was not possible to apply electrolytic enrichment due to the small sample amount.

\subsection{Electrolytic conductivity}

Specific electrolytic conductivity (EC) was measured on melted water samples at the Institute of Nuclear Research (HAS) using a LABCOR Consort C533 instrument. Results were corrected to $25^{\circ} \mathrm{C}$ and are reported in $\mu \mathrm{S} \mathrm{cm}^{-1}$.

\subsection{Stable isotope analysis}

Stable oxygen and hydrogen isotope measurements were carried out using the $\mathrm{CO}_{2}-\mathrm{H}_{2} \mathrm{O}$ equilibration method (Epstein and Mayeda, 1953) and the $\mathrm{H}_{2}-\mathrm{H}_{2} \mathrm{O}$ equilibration using a Ptcatalyst (Prosser and Scrimgeour, 1995). One $\mathrm{ml}$ water was used for $\delta^{18} \mathrm{O}$ and $1 \mathrm{ml}$ for $\delta \mathrm{D}$ determination. The equilibrated $\mathrm{CO}_{2}$ and $\mathrm{H}_{2}$ gases were measured using a Finnigan Delta ${ }^{\text {plus }} \mathrm{XP}$ mass spectrometer in continuous-flow mode at the Institute for Geochemical Research, HAS.

Stable isotope values are expressed in the conventional delta notation relative to the Vienna Standard Mean Ocean Water (VSMOW) standard. A two-point linear normalization was applied to calibrate the raw data (Paul et al., 2007). The precision of the measurements are $\pm 0.2 \%$ and $\pm 2.0 \%$ o for $\delta^{18} \mathrm{O}$ and $\delta \mathrm{D}$, respectively. All samples were analysed in duplicate and measurements were repeated when duplicates showed a larger difference than the analytical uncertainty.

\subsection{Insoluble residue}

As many samples were distilled for tritium measurements during an earlier stage of this research, only a few samples could be studied over the upper $1.65 \mathrm{~m}$ of the core for the insoluble residue and the record is continuous only from sample MH32 downward.

Insoluble impurities were inspected using a binocular microscope (Zeiss Discovery V20 SteREO) and four types could be distinguished:

a. white or yellowish micro-plates with serrated edges and fluffy aggregates,

b. ochre-coloured mud,

c. black particles,

d. small limestone fragments

The most abundant types are the first two ones. In order to characterize the relative abundance, the following simple classification scheme was applied:

0 . absent

1. present

2. abundant

\subsection{Reference data for local precipitation and springwater}

The dataset from the nearest station of the Austrian Network of Isotopes in Precipitation (ANIP) at Feuerkogel $\left(47.82^{\circ} \mathrm{N}\right.$, $13.72^{\circ} \mathrm{E}, 1598 \mathrm{~m}$ a.s.1.) (Fig. 1) was used as a reference for the isotopic characteristics $\left(\delta \mathrm{D}, \delta^{18} \mathrm{O},{ }^{3} \mathrm{H}\right)$ of the lo$\mathrm{cal} /$ regional precipitation of the study site. This mountain 
station can be regarded as not affected by sub-cloud evaporation processes (Fröhlich et al., 2008). In addition, the $\delta^{18} \mathrm{O}$ dataset is nearly identical to precipitation collected over a shorter period at Krippenstein ( $2100 \mathrm{~m}$ a.s.l.; Scheidleder et al., 2001) right above the cave (see Supplement); thus, the Feuerkogel station is an appropriate reference for the catchment of the Mammuthöhle system. The monthly mean tritium concentration of past precipitation in Vienna was obtained from the ISOHIS database (IAEA, 2004). Current levels of tritium activity were calculated using a half-life of $12.32 \mathrm{yr}$ (Lucas and Unterweger, 2000).

The three nearest karst springs were selected from the dataset of karst water monitoring network of the Dachstein area (Scheidleder et al., 2001). These are the Koppenbrüllerquellen, Meisenbachquelle and Hirschbrunn. Their stable isotope and electrolytic conductivity data were used as a reference of the local karst water. Conductivity values of these three springs ranged from 9 to $200 \mu \mathrm{S} \mathrm{cm}^{-1}$. The lowest value seems to be an outlier as it is not only unusual for karst water but also close to the lowest range of local rainwater (3-20 $\mu \mathrm{S} \mathrm{cm}^{-1}$, Kralik et al., 2005). The other data show values in excess of $120 \mu \mathrm{S} \mathrm{cm}^{-1}$ and this value was adopted as a threshold for the range of the "local karst water".

\section{Results and discussion}

\subsection{Tritium data}

Serial ${ }^{3} \mathrm{H}$ measurements is a powerful tool to date cave ice deposited from precipitation during the past $\sim 60 \mathrm{yr}$ (Horvatinčić 1996; Horvatinčić and Krajcar-Bronić, 1998; Kern et al., 2009b). However, in the present case the tritium activities were uniformly below the detection limit $(8.5 \mathrm{TU})$ of the method. Keeping in mind that the Saarhalle ice body has shown a continuously negative mass balance since 1996 ( $-7 \mathrm{~cm} \mathrm{yr}^{-1}$; Mais and Pavuza, 2000; unpubl. data.), this fact not only excludes the existence of recent ice at the surface but also corresponds with $91 \mathrm{~cm}$ of cumulative ice loss during the past $13 \mathrm{yr}$.

Comparing the detection limit $(8.5 \mathrm{TU})$ of the decaycorrected time series of precipitation at Feuerkogel and Vienna it is evident that precipitation fallen between $\sim 1961$ and 1981 should still exceed this level (Fig. 2). Consequently, all analysed ice samples are older than 1961 or younger than 1981. Considering the observed ice loss we estimate that the accumulation rate prior to 1996 was slower than $2.61 \mathrm{~cm} \mathrm{yr}^{-1}$ if today's uppermost layer is older than 1961 . Alternatively, the average accumulation rate should had been higher than $14 \mathrm{~cm} \mathrm{yr}^{-1}$ prior to 1996 if the lowermost measured sample is younger than 1981 .

Historical observations do not support periods of pronounced ice formation prior to 1996 . Keeping in mind that the observed inter-annual fluctuation of ice surface changes

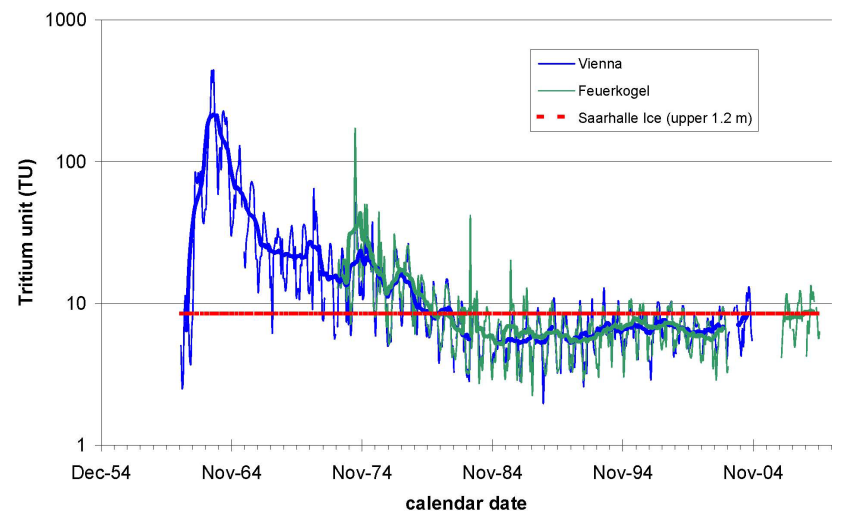

Fig. 2. Decay-corrected tritium activity of precipitation at Feuerkogel (green) and Vienna (blue). Thin lines and thick lines show monthly values and 12-months moving average, respectively. Horizontal red line marks the 8.5 TU detection level.

also showed only a modest variability since the onset of systematic monitoring we regard an abrupt shift from a very high accumulation rate (i.e. $14 \mathrm{~cm} \mathrm{yr}^{-1}$ ) to the observed rate of $-7 \mathrm{~cm} \mathrm{yr}^{-1}$ as unlikely. So we reckon that the uppermost ice layer of the core formed from precipitation fallen before the 1960s.

\subsection{Conductivity and insoluble residue}

EC values range from 39.6 to $220 \mu \mathrm{S} \mathrm{cm}^{-1}$. EC shows less variability over the upper $1.3 \mathrm{~m}$ of the core and in the section below $3.3 \mathrm{~m}$. In contrast, EC exhibits large fluctuations in between. A comparison with values of the local karst springs shows that cave ice samples largely overlap with the values of the karst springs except for some very low EC values (Fig. 3a). Two possible reasons could explain the lower values measured in the ice core. Firstly, they might indicate water from fast infiltration which had minimal contact with the soil or the carbonate host rock. Secondly, an ice layer formed by condensation and freezing of water vapour could also result in low conductivity values.

The correlation between EC and the three abundance classes of "white/yellowish micro-plates and aggregates" and "ochre mud" are $r=-0.12$ and $r=0.7$, respectively. This indicates that the main cause of EC variability in the Saarhalle ice core is not linked to the presence of cryocalcite but is associated with changes in the ion content of the water source.

EC values of ice of Eisriesenwelt cave (Tennengebirge Mts, Austria) are similarly variable but characteristically lower than those from Saarhalle (May et al., 2011), despite the fact that both caves developed in the same host rock and occur at similar elevations. In addition, May et al. (2011) observed a different relationship between EC and the occurrence and abundance of insoluble particles. This suggests 


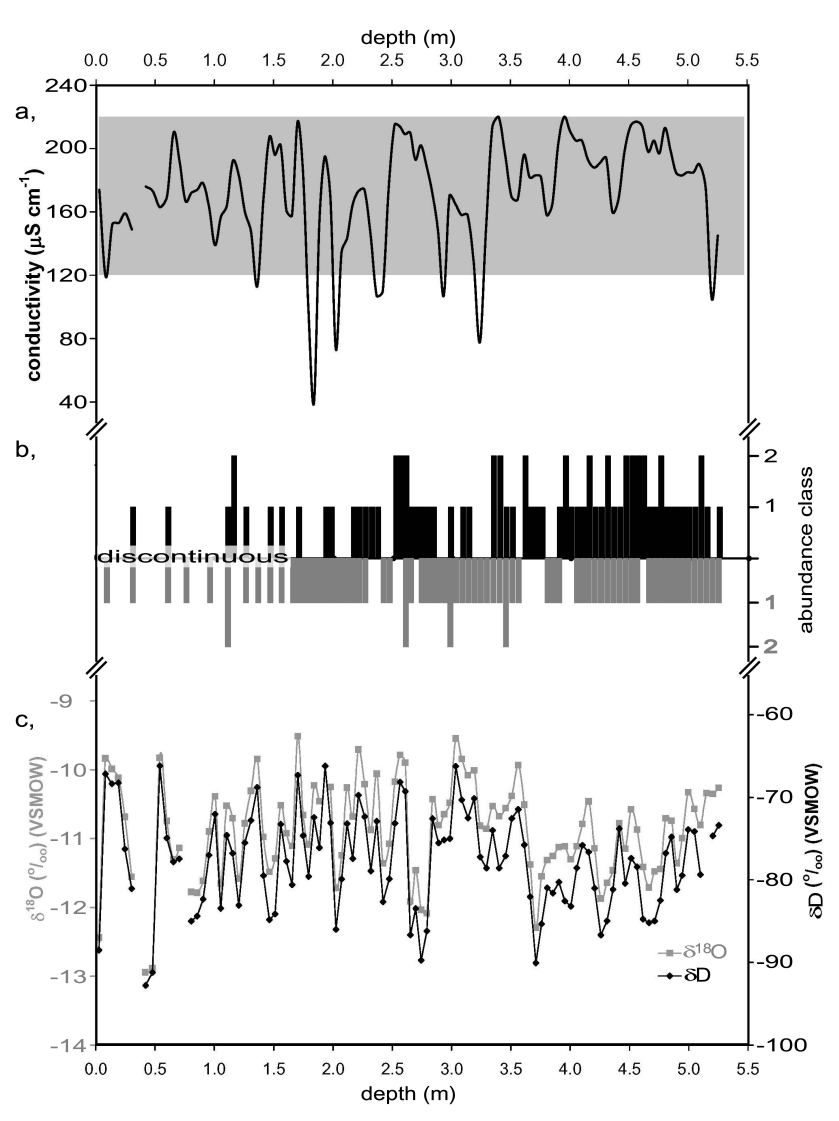

Fig. 3. Diagram summarizing the analytical results of the $5.28 \mathrm{~m}-$ long cave ice core extracted from the Saarhelle ice body. (a) Electrolytic conductivity profile of the ice core superimposed on the EC range of local karst springs from the Koppenwinkel area (light grey shaded). (b) Abundance (0-absent, 1-present, 2-abundant) of insoluble particles in the ice core samples: "ochre-coloured mud" (black columns), "white-yellowish micro-plates and aggregates" (grey columns). Note the reversed scale for the latter. (c) Stable oxygen (grey) and hydrogen (black) isotope composition of the ice samples.

local differences in the partitioning between karst water and surface water in the cave ice accumulation in the two cave systems.

Other insoluble particles are far less common in the Saarhalle ice samples. Black grains were observed in two samples (MH92, $4.62 \mathrm{~m}$ and MH98, 4.9 m) and require further investigation. Finally, small angular limestone fragments were also observed in two ice samples (MH98, $4.81 \mathrm{~m}$ and MH102, $5.1 \mathrm{~m}$ ). They possibly indicate enhanced frost shattering events in the past.

\subsection{Stable water isotopes}

Stable isotopic data of the cave ice samples range from $-12.95 \%$ o to $-9.51 \%$ and from $-92.8 \%$ o to $-66.2 \%$ for $\delta^{18} \mathrm{O}$ and $\delta \mathrm{D}$, respectively (Fig. 3c). The isotope values are weakly anti-correlated with EC ( $r=-0.18$ for $\delta^{18} \mathrm{O}$ vs. EC, $p=0.01)$. Deuterium excess $\left(d=8^{*} \delta^{18} \mathrm{O}+10\right.$, Dansgaard, 1964) varies between 6.2 and 12.7.

The mean stable oxygen isotopic composition of the cave ice $(-10.88 \%$ ) is less depleted than the mean values of both potential sources, i.e. the long-term (1973-2003) amount-weighted annual mean $\delta^{18} \mathrm{O}$ value of precipitation at Feuerkogel $(-12.79 \%$ ) and the average of the three karst springs $(-12.16 \%$; Table 1$)$. One potential explanation could be a seasonality bias, i.e. cave ice formation during certain periods of the year only. Given the fact that ice formation occurs preferentially during spring the expected heavy isotope ratio should actually be lower than that of the outside mean annual precipitation, i.e. the opposite of what is observed in our samples. This is supported by the $d$-excess values which are lower than those of the precipitation or the springs for all seasons. These lower $d$-excess values together with the comparably high isotope values strongly hint toward kinetic fractionation during ice formation, i.e. preferential incorporation of the heavy isotopes of $\mathrm{H}$ and $\mathrm{O}$ into the ice. The process is known from basal ice of glaciers where repeated melting-freezing cycles take place (Jouzel and Souchez, 1982) and has been suggested for other cave ice occurrences (e.g. Citterio et al., 2004; May et al., 2011; Persoiu et al., 2011). Assuming freezing in a closed system the estimated freezing slope is $\sim 6.7$ as calculated by the JouzelSouchez model using the fractionation factors of Lehmann and Siegenthaler (1991) and either the karst water or annual mean of the amount-weighted precipitation from Feuerkogel. However, an open-system approach could represent a more adequate model for the ice formation in the Saarhalle. In an open-system slightly lower slopes are expected (Souchez and Jouzel, 1984). However, the cave ice data from the Saarhalle do not tend to diverge from the water line of the potential source waters (Fig. 4). The calculated slope of the cave ice water line is above 8 (Table 1). Hence these findings can be explained neither by closed-system freezing nor by a simple open-system model.

Souchez and de Groote (1985) studied the basal ice of Grubengletscher. They found a lower $d$-excess in basal ice compared to glacier ice (regarded as reflecting annual precipitation) and the slope of the $\delta^{18} \mathrm{O}$ vs. $\delta \mathrm{D}$ regression was 8.19 for basal ice compared to 7.96 for the glacier ice. They simulated the process where isotopically depleted water was mixed with initial water in the course of freezing. They found that if the input rate of the depleted component is relatively high compared to the freezing rate the deposited ice is isotopically enriched relatively to the parent water and the water line approaches 8 but with a lower $d$-excess.

Karst springs from the Koppenwinkel area of the Dachstein Mts show that less depleted water is present in the karst aquifer in early springtime before snowmelt (Scheidleder et al., 2001). When the peak of snowmelt-derived water arrives (April-May) karst water becomes most depleted in the annual cycle. A similar phase shift has been recently 
Table 1. Basic statistics of $\delta^{18} \mathrm{O}$ and $d$-excess data of the Saarhalle ice core compared to the regional atmospheric precipitation (Feuerkogel, ANIP, 2010) and local karst springs (Scheidleder et al., 2001).

\begin{tabular}{|c|c|c|c|c|c|c|c|}
\hline & $\delta^{18} \mathrm{O} \%$ & & & xcess & & & $\mathrm{s}^{\mathrm{a}}$ \\
\hline & Mean & $\mathrm{SD}^{\mathrm{b}}$ & $\operatorname{Min} / \max$ & Mean & $\mathrm{SD}^{\mathrm{b}}$ & $\operatorname{Min} / \max$ & \\
\hline All & -10.88 & 0.70 & $-12.95 /-9.51$ & 9.2 & 1.5 & $6.2 / 12.7$ & 8.13 \\
\hline Low $\mathrm{EC}^{\mathrm{c}}$ & -10.68 & 0.62 & $-11.72 /-9.84$ & 8.8 & 0.9 & $7.6 / 10.0$ & 8.5 \\
\hline normal $\mathrm{EC}^{\mathrm{d}}$ & -10.90 & 0.71 & $-12.95 /-9.516$ & 9.2 & 1.5 & $6.2 / 12.7$ & 8.07 \\
\hline Feuerkogel $^{\mathrm{e}}$ & -12.79 & 0.74 & $-14.46 /-11.75$ & 13.2 & 1 & $10.7 / 15.2$ & 8.25 \\
\hline Summere & -9.92 & 0.89 & $-11.65 /-8.08$ & 13.3 & 0.9 & $11.7 / 15.4$ & 8.02 \\
\hline Winter ${ }^{\mathrm{e}}$ & -14.05 & 1.64 & $-17.23 /-10.77$ & 11.4 & 1.5 & $9.3 / 15.1$ & 8.03 \\
\hline Karst springs & -12.16 & 1.27 & $-15.01 /-9.41$ & 10.9 & 0.9 & $9.4 / 13$ & 7.85 \\
\hline
\end{tabular}

${ }^{\text {a }}$ Slope of the $\delta^{18} \mathrm{O}$ vs. $\delta \mathrm{D}$ regression; ${ }^{\mathrm{b}}$ standard deviation; ${ }^{\mathrm{c}}$ samples with $\mathrm{EC}<120 \mu \mathrm{S} \mathrm{cm}^{-1}{ }^{\mathrm{d}}{ }^{\mathrm{d}}$ samples with $\mathrm{EC}>120 \mu \mathrm{S} \mathrm{cm}{ }^{-1} ;^{\mathrm{e}}$ amount-weighted annual/seasonal mean.

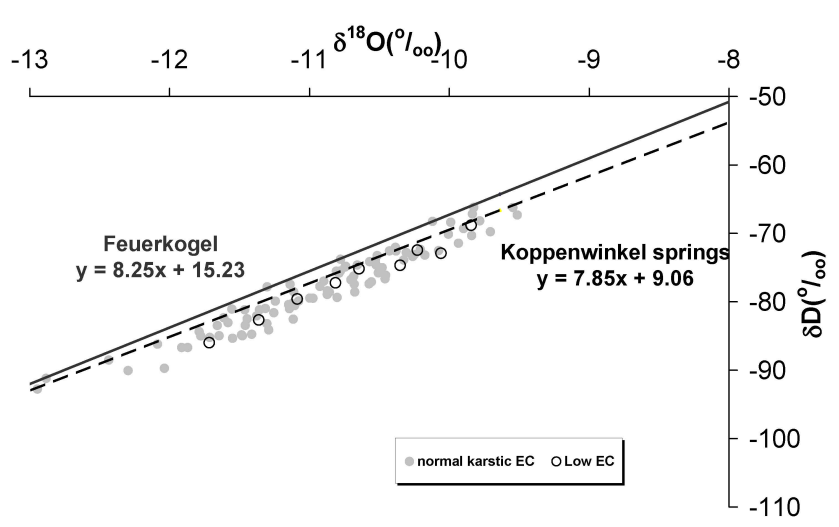

Fig. 4. Stable isotopic characteristics of the Saarhalle ice core and its potential sources. The local meteoric water line is based on monthly data of the Feuerkogel precipitation station (ANIP, 2010) over the 1973-2009 period (dark grey). The dashed line is the karstic water line defined by data of the three nearest karst springs in the Koppenwinkel area (Scheidleder et al., 2001).

reported from a Romanian ice cave (Kern et al., 2009a), where late spring ice accumulation was fed by drip water isotopically comparable to that of the previous winter precipitation due to the delay effect of infiltration.

For the case of the Saarhalle ice body the isotopically less depleted spring karst water could play the role of the first component mixed with snowmelt (the heavily depleted second component).

It is important to note that the isotope compositions of those ice layers with low EC values are not different from the other samples (Fig. 4). Had these ice layers originated from freezing of water vapour they should plot well above the local meteoric water line (Lauriol and Clark, 1993; Lacelle et al., 2009). Since this is not the case we suggest a flush-like inflow through the epikarst into the Saarhalle which could account for water characterized by low conduc- tivity values. Freezing definitely shifted the composition of these layers towards less depleted isotope values. However, as the mean isotopic composition is slightly higher and the $d$-excess slightly lower in these low-EC samples than for the rest of the ice core a less depleted input component is suggested by the open-system mixing model. We hypothesize that the flushes preserved in these low-EC layers might have originated from early spring rain which is characteristically less depleted than winter precipitation and the $d$-excess of spring precipitation is lowest in this region (Fröhlich et al., 2008).

\section{Conclusions}

The upper $\sim 1.2 \mathrm{~m}$ of ice and the uppermost ice layer likely formed from precipitation fallen before the 1960s (based on $<8.5 \mathrm{TU})$

The cave ice samples show similar EC values to the local karst water, except for a few ice layers with significantly lower EC values. Stable isotope data argue against freezing of water vapour as a cause for these low EC values.

The isotopic characteristics of the cave ice samples can be explained by a mixed-component open-system freezing model as described by Souchez and de Groote (1985), i.e. isotopically less depleted early spring karst water mixes with isotopically strongly depleted snowmelt water.

Determining the age of the ice deposit remains a challenge. We will try dating using the ${ }^{3} \mathrm{H}_{-}{ }^{3} \mathrm{He}$ ingrowth method (detection limit $\sim 0.1 \mathrm{TU}$; Palcsu et al., 2010). In addition, the correlation of GPR profile (Hausmann and Behm, 2010) with conductivity and stable isotope profiles is an exciting future task. 


\section{Supplementary material related to this article is available online at: http://www.the-cryosphere.net/5/291/2011/ tc-5-291-2011-supplement.zip.}

Acknowledgements. Special thanks to Michael Behm and Helmut Hausmann (Vienna University of Technology, Research Group Geophysics) for their help in the cave. The photograph of the Saarhalle ice body was kindly provided by Andreas Neumann. Thanks to Christoph Spötl for his help to get access to stable isotope reference data of the local precipitation and to Dietmar Wagenbach for his advice on conductivity. The authors acknowledge Dachsteinhöhlen Cave Management (Stephan Höll) for permission to study the cave ice. Thanks to TÁMOP 4.2.1./B09/KMR-2010-0003 and OTKA K67583. The mass spectrometer facility of the IGR was financed by NKTH, project number: GVOP-3.2.1.-2004-04-0235/3.0. Martin Kralik and an anonymous reviewer are greatly acknowledged due to their useful comments on the initial version of the manuscript.

Edited by: C. Spötl

\section{References}

ANIP: Austrian Network of Isotopes in Precipitation, Umweltbundesamt: http://www.umweltbundesamt.at/umweltinformation/ wasser/isotopen/isotopen, last access: 27 October 2010, 2010.

Behm, M. and Hausmann, H.: Eisdickenmessungen in alpinen Höhlen mit Georadar, Die Höhle, 58, 3-11, 2007.

Behm, M. and Hausmann, H.: Determination of ice thickness in Alpine caves using georadar, in: 3rd International Workshop on Ice Caves Proceedings, edited by: Kadebskaya, O., Mavlyudov, B. R., and Pyatunin, M. Kungur, 53-58, 2008.

Citterio, M., Turri, S., Bini, A., and Maggi, V.: Observed trends in the chemical composition, $\delta^{18} \mathrm{O}$ and crystal sizes vs. depth in the first core from the LoLc 1650 "Abisso sul margine dell'Alto Bregai” ice cave (Lecco, Italy), Theor. Appl. Karst, 17, 45-50, 2004.

Clausen, H. B., Vrana, K., Hansen, S. B., Larsen, L. B., Baker, J., Siggaard-Andersen, M.-L., Sjolte, J., and Lundholm, S. C.: Continental ice body in Dobšiná Ice Cave (Slovakia) - part II. - Results of chemical and isotopic study, in: Proceedings of the 2nd International Workshop on Ice Caves Liptovsky Mikulás, edited by: Zelinka, J., 29-37, 2007.

Curie, L. A.: Nomenclature in evaluation of analytical methods including detection and quantification capabilities, (IUPAC Recommendation 1995), Pure Appl. Chem., 67, 1699-1723, 1995.

Dansgaard, W.: Stable isotopes in precipitation, Tellus, 16, 436468, 1964.

Epstein, S. and Mayeda, T.: Variation of ${ }^{18} \mathrm{O}$ content of waters from natural sources, Geochim Cosmochim Ac., 4, 89-103, 1953.

Frisch, W., Kuhlemann, J., Dunkl, I., Székely, B., Vennemann, T., and Rettenbacher, A.: Dachstein-Altfläche, AugensteinFormation und Höhlenentwicklung - die Geschichte der letzten 35 Millionen Jahre in den zentralen Nördlichen Kalkalpen, Die Höhle, 53, 1-36, 2002.

Fröhlich, K., Kralik, M., Papesch, W., Rank, D., Scheifinger, H., and Stichler, W.: Deuterium excess in precipitation of Alpine
Regions - Evaluation of sub-cloud evaporation and moisture recycling, Isot. Environ. Health S., 44, 61-70, 2008.

Fórizs, I., Kern, Z., Nagy, B., Szántó, Zs., Palcsu, L., and Molnár, M.: Environmental isotope study on perennial ice in the Focul Viu Ice Cave, Bihor Mts., Romania, Theor. Appl. Karst, 17, 6169, 2004.

Haeberli, W., Frauenfelder R., Kääb, A., and Wagner S.: Characteristics and potential climatic significance of "miniature ice caps" (crest- and cornice-type low-altitude ice archives), J. Glaciol., 50, 129-136, 2004.

Hausmann, H. and Behm, M.: Application of ground penetrating radar (GPR) in Alpine ice caves, The Cryosphere Discuss., 4, 1365-1389, doi:10.5194/tcd-4-1365-2010, 2010.

Holmlund, P., Onac, B. P., Hansson, M., Holmgren, K., Mörth, M., Nyman, M., and Perşoiu, A.: Assessing the palaeoclimate potential of cave glaciers: the example of Scarişoara Ice Cave (Romania), Geogr. Ann., 87 A, 193-201, 2005.

Horvatinçić, N.: Isotopic measurement in ice, Ledenica Cave, Velebit, Croatia., (In Croatian with English summary) in: Proceedings of the third symposium of the Croatian Radiation Protection Association, edited by: Kubelka, D. and Kovaè, J. Zagreb, 297-302, 1996.

Horvatinçić, N. and Krajcar-Bronić, I.: $14 \mathrm{C}$ and $3 \mathrm{H}$ as indicators of the environmental contamination, RMZ - Materials and Geoenvironment, 45, 56-60, 1998.

IAEA: Isotope Hydrology Information System. The ISOHIS Database, http://isohis.iaea.org, 2004.

Jouzel, J. and Souchez, R. A.: Melting-refreezing at the glacier sole and the isotopic composition of the ice, J. Glaciol., 28, 35-42, 1982.

Kern, Z., Fórizs, I., Perşoiu, A., and Nagy, B.: Stable isotope study of water sources and of an ice core from the Borig Ice Cave, Romania, Data Glac. Stud. (Materialy Glyatsiologicheskikh Issledovaniy), 107, 175-182, 2009a.

Kern, Z., Molnár, M., Svingor, É., Perşoiu, A., and Nagy B.: High resolution, well preserved tritium record in the ice of Borig Ice Cave, Bihor Mountains, Romania, The Holocene, 19, 729-736, doi:10.1177/0959683609105296, 2009b.

Kralik, M., Zieritz, I., Grath, J., Vincze, G., Philipitsch, R., and Pavlik, H.: Hydrochemical map of Austria, Umweltbundesamt, Wien, 15, 2005.

Lacelle, D., Lauriol, B., and Clark, I. D.: Formation of seasonal cave ice and associated cryogenic carbonates in Caverne de l'Ours, Québec, Canada, Kinetic isotope effects and pseudobiogenic crystal structures, J. Cave Karst Stud., 71, 48-62, 2009.

Lauriol, B. and Clark, I. D.: An approach to determine the origin and age of massive ice blockages in two Arctic caves, Permafrost Periglac. Proc., 4, 77-85, 1993.

Lehmann, M. and Siegenthaler, U.: Equilibrium oxygen- and hydrogen-isotope fractionation between ice and water, J. Glaciol., 37, 23-26, 1991.

Lucas, L. L. and Unterweger, M. P.: Comprehensive review and critical evaluation of the half-life of tritium, J. Res. Natl. Inst. Stand. Technol, 105, 541-49, 2000.

Luetscher, M. and Jeannin, P.: A process-based classification of alpine ice caves, Theor. Appl. Karst, 17, 5-10, 2004.

Luetscher, M., Bolius, D., Schwikowski, M., Schotterer, U., and Smart, P. L.: Comparison of techniques for dating of subsurface ice from Monlesi ice cave, Switzerland, J. Glaciol., 53, 374-84, 
2007.

Mais, K. and Pavuza, R.: Hinweise zu Höhlenklima und Höhleis in der Dachstein Mammuthöhle (Oberösterreich), Die Höhle, 51, 121-125, 2000.

May, B., Spötl, C., Wagenbach, D., Dublyansky, Y., and Liebl, J.: First investigations of an ice core from Eisriesenwelt cave (Austria), The Cryosphere, 5, 81-93, doi:10.5194/tc-5-81-2011, 2011.

Obleitner, F. and Spötl, C.: The mass and energy balance of ice within the Eisriesenwelt cave, Austria, The Cryosphere, 5, 245257, doi:10.5194/tc-5-245-2011, 2011.

Palcsu, L., Major, Z., Köllő, Z., and Papp, L.: Using an ultrapure ${ }^{4} \mathrm{He}$ spike in tritium measurements of environmental water samples by the ${ }^{3} \mathrm{He}$-ingrowth method, Rapid Commun. Mass Sp., 24, 698-704, doi:10.1002/rcm.4431, 2010.

Paul, D., Skrzypek, G., and Fórizs, I.: Normalization of measured stable isotopic compositions to isotope reference scales - a review, Rapid Commun. Mass Sp., 21, 3006-3014, doi:10.1002/rcm.3185, 2007.

Perşoiu, A.: Ice speleothemes in Scărişoara Cave: dynamics and controllers, Theor. Appl. Karst, 17, 71-76, 2004.

Perşoiu, A., Bojar, A.-V., and Onac, B. P.: Stable isotopes in cave ice: what do they tell us?, Stud. Univ. Babeş-Bolyai, Geologia, 52, 59-62, 2007.

Perşoiu, A., Onac, B. P., Wynn, J., Bojar, A.-V., and Holmgren, K.: Stable isotopes behavior during cave ice formation by water freezing in Scărişoara Ice Cave, Romania, J. Geophys. Res., 116, D02111, doi:10.1029/2010JD014477, 2011.

Plan, L. and Xaver, A.: Geomorphologische Untersuchung und genetische Interpretation der Dachstein-Mammuthöhle (Österreich), Die Höhle, 61, 18-38, 2010.

Prosser, S. J. and Scrimgeour, C. M.: High-precision determination of $2 \mathrm{H} / 1 \mathrm{H}$ in $\mathrm{H}_{2}$ and $\mathrm{H}_{2} \mathrm{O}$ by continuous-flow isotope ratio mass spectrometry, Anal. Chem., 67, 1992-1997, 1995.

Rajman, L., Roda, Š., Roda jr., Š., and Šuka, J.: Termodynamický režim Silickej l'adnice, Slovenský kras, 25, 29-61, 1987.

Reimer, P. J., Baillie, M. G. L., Bard, E., Bayliss, A., Beck, J. W., Blackwell, P. G., Bronk Ramsey, C., Buck, C. E., Burr, G., Edwards, R. L., Friedrich, M., Grootes, P. M., Guilderson, T. P., Hajdas, I., Heaton, T. J., Hogg, A. G., Hughen, K. A., Kaiser, K. F., Kromer, B., McCormac, F. G., Manning, S. W., Reimer, R. W., Richards, D. A., Southon, J., Turney, C. S. M., van der Plicht, J., and Weyhenmeyer, C.: IntCal09 and Marine09 radiocarbon age calibration curves, 0-50 000 years cal BP, Radiocarbon 51, 1111-1150, 2009.
Schwikowski, M.: Reconstruction of European Air Pollution from Alpine Ice Cores, in: Earth Paleoenvironments: Records Preserved in Mid- and Low-Latitude Glaciers, edited by: Cecil, L. D., Green, J. R., and Thompson, L. G., Kluwer Academic Publishers, Dordrecht, 95-119, 2004.

Scheidleder, A., Boroviczeny, F., Graf, W., Hofmann, T., Mandl, G., Schubert, G., Stichler, W., Trimborn, P., and Kralik, M.: Pilotprojekt "Karstwasser Dachstein": vol. 2 Karsthydrologie und Kontaminationsrisiko von Quellen, Umweltbundesamt Monographie, 108, 1-155, Wien, Umweltbundesamt, 2001.

Souchez, R. A. and de Groote, J. M.: $\delta \mathrm{D}-\delta^{18} \mathrm{O}$ relationships in ice formed by subglacial freezing: Paleoclimatic implications, J. Glaciol., 31, 369-372, 1985.

Souchez, R. A. and Jouzel, J.: On the isotopic composition in $\delta \mathrm{D}$ and $\delta^{18} \mathrm{O}$ of water and ice during freezing, J. Glaciol., 30, 369372, 1984.

Svetlik, I. and Budska, E.: Monitoring of tritium in atmospheric precipitation, Bezpec̀ost jaderné energie (The Safety of Nuclear Energy), 9, 251-254, 2001.

Turri, S., Maggi, V., and Bini, A.: Ice caves as natural archives in the palaeoclimatic studies, Data Glac. Stud. (Materialy Glyatsiologicheskikh Issledovaniy), 107, 163-169, 2009.

Wagenbach, D.: Environmental records in alpine glaciers and ice sheets, Dahlem Konferenzen, John Wiley, Chichester, 69-83, 1989.

Wagenbach, D. and Spötl, C.: Cave ice in the Alpine glacier archives, in: 4th International Workshop on Ice Caves, edited by: Spötl, C., Luetscher, M., Rittig, P., Obertraun, Austria,, 40, 5-11, June 2010.

Yonge, C. J. and MacDonald, W. D: The contrast in isotopic composition of cave ice across the divide in Western North America. in: Archives of Climate Change, edited by: Onac, B. P., Tudor, T., Constantin, S., and Perşoiu, A., Karst Water Institute Special Publications, 10, 26-28, 2006. 